\title{
Persepsi Dan Partisipasi Masyarakat Desa Giritirto Kecamatan Purwosari Gunung Kidul Terhadap Kegiatan Program Posyandu
}

\author{
Oleh: Puji Lestari ${ }^{1}$
}

\section{Abstracts}

The objective of this research is to understand the development of activities, participations, and perception on POSYANDU program and to understand the correlation between perception and participation of all the society according to social economy and social culture conditions

The method of descriptive qualitative is used in this research for the reason that this method is able to convey and to uncover a lot of information with more in accuracy and meaning. Despite bringing into play the qualitative method, the quantitative method is not being put aside as well. From every object observed, a tendency, patterned ways of think, irregularity, and behavioral appearance and its integration as in genetic study of case will be seen. Genetic study of case is being used as a strategy of research since the issues and focus of this research have been determined before in the research proposal prior to field research. Hence, research strategy afterward is included as the embedded of research study of case.

This research then wraps up and comes into the conclusion that POSYANDU program in the village of Giri Tirto is consistently implemented which has developed into society's tradition. The varieties of society's participations in POSYANDU program are limited to their comprehension and understanding about what POSYANDU program is. The most participating party in this program is the families who have a baby (less than five years-old baby), while the worker's contribution is to give service to baby growth. The role of the elite figures and village peripherals are very limited in giving advice for POSYANDU Activities. The character of a simple life is also expressed in simple behaviors in daily life.

Keywords: Participation, POSYANDU, Perception, Society, Program.

\footnotetext{
${ }^{1}$ Dosen Jurusan Pendidikan Sejarah Fakultas Ilmu Sosial dan Ekonomi Universitas Negeri Yogyakarta.
} 


\section{A. Pendahuluan}

Untuk mengembangkan berbagai aspek kehidupan dalam rangka meningkatkan kesejahteraan masyarakat bangsa Indonesia, pemerintah selama ini telah berusaha mengembangkan banyak program dengan melibatkan berbagai lembaga yang ada dalam masyarakat. Program tersebut telah dilaksanakan guna menjangkau warga masyarakat lapisan paling bawah sebagai sasaran utamanya bagi landasan usaha peningkatan kesejahteraan masyarakat bangsa secara menyeluruh.

Dalam tiap program pengembangan masyarakat dewasa ini, partisipasi aktif seluruh warga masyarakat dipandang sangat penting artinya bagi kelancaran pelaksanaan kegiatan dan tercapainya tujuan secara mantap. Oleh karena itu partisipasi masyarakat selalu diusahakan untuk dikembangkan sejak awal pelaksanaan program, dan diharapkan bisa berlangsung terus sampai tercapai tujuan programnya (Harsojo, 1999: 210)

Dalam mengembangkan peran serta masyarakat pada program tertentu, para tokoh masyarakat baik formal maupun non formal sangat penting peranannya, terutama dalam mempengaruhi, memberi contoh, dan menggerakkan keterlibatan seluruh warga masyarakat lingkungannya guna mendukung keberhasilan program. Lebih-lebih dalam masyarakat pedesaan, peran tersebut menjadi sangat menentukan karena kedudukan para tokoh masyarakat masih sangat kuat pengaruhnya, dan bahkan sering menjadi tokoh panutan dalam segala kegiatan hidup sehari-hari warga masyarakatnya.

Persepsi warga masyarakat terhadap kegiatan program tertentu merupakan landasan atau dasar utama bagi timbulnya kesediaan untuk ikut terlibat dan berperan secara aktif dalam setiap kegiatan program tersebut. Makna positif atau negatif sebagai hasil persepsi seseorang terhadap program akan menjadi pendorong atau penghambat baginya untuk berperan dalam kegiatannya.

Berbagai hal yang terjadi dan menjadi pengalaman yang kurang menyenangkan sering mengakibatkan warga masyarakat kurang bersikap terbuka untuk secara jujur menyatakan persepsi dan pandangannya tentang suatu program kegiatan yang secara resmi diselenggarakan oleh pemerintah. Karena sering dilandasi oleh 
persepsi yang kurang positif maka keterlibatan yang ada sering merupakan partisipasi semu. Keadaan sedemikian itu bila terjadi, sering membawa akibat kurang lancarnya kegiatan sesuai dengan rencana sehingga menyulitkan usaha pencapaian tujuan program secara utuh dan mantap (Sutopo, 1996: 132).

Selama ini banyak program pemerintah dalam usaha pengembangan masyarakat telah dirancang dan diputuskan hanya berdasarkan konsep, dan pertimbangan dari atas (top down), tanpa memperhatikan kekhususan latar belakang sosial, ekonomi, dan budayanya, yang sangat memungkinkan terjadinya perbedaan persepsi antarwarga masyarakat terhadapnya. Akibatnya banyak program menghadapi kendala dalam pelaksanaannya, terutama dalam mengembangkan partisipasi aktif masyarakat sebagai komponen utama dalam mencapai keberhasilan program. Kegagalan dalam mengembangkan partisipasi aktif warga masyarakat tersebut selama ini tidak banyak dijelaskan, karena proses interaksi warga masyarakat serta makna persepsinya terhadap kegiatan yang sedang dikembangkan, yang sebenarnya sangat dipengaruhi oleh kekhususan kondisi sosial ekonomi dan budayanya tak banyak menjadi sasaran pengkajian secara teliti dalam proses perencanaan program.

Proses dan makna persepsi seseorang tidak mudah untuk diungkap secara lengkap dan rinci, lebih-lebih bila seseorang tersebut kurang bersikap terbuka. Banyak hal yang merupakan pengalaman seseorang dapat mempengaruhi makna hasil persepsi terhadap kegiatan hubungan antar manusia dalam masyarakat. Selain tergantung dari bentuk dan proses interaksinya, persepsi seseorang sangat tergantung pada banyak faktor yang membentuk pengalamanya dalam kehidupan masyarakat itu sendiri. Faktorfaktor tersebut antara lain meliputi kondisi sosial ekonomi, corak budaya yang berkaitan dengan agama yang dianutnya, kepercayaan, dan tradisi hidup keseharian dari warga masyarakatnya. Semuanya itu membentuk karakteristik masyarakat tertentu, yang bisa sangat berbeda dengan masyarakat lain di tempat yang lain pula. Dalam kaitannya dengan program posyandu sebagai usaha pemerintah untuk meningkatkan kesejahteraan masyarakat lewat program 
pengembangan kesehatan anak, maka partisipasi aktif warga masyarakat juga akan sangat ditentukan oleh persepsinya terhadap kegiatan posyandu yang sangat dipengaruhi oleh latar belakang sosial ekonomi dan budayanya yang khusus.

Pembahasan ini mengambil kasus Desa Giritirto Kecamatan Purwosari Kabupaten Gunung Kidul Daerah Istimewa Yogyakarta sebagai wilayah kajiannya. Desa Giritirto dipilih karena memiliki karakteristik wilayah yang unik yakni bahwa wilayah Giritirto merupakan pusat hubungan antar desa di Kecamatan Purwosari Gunung Kidul, tetapi memiliki beberapa pedukuhan yang masih sangat terisolasi. Oleh karena itu, menjadi menarik untuk menelaah tentang persepsi dan partisipasi masyarakat Desa Giritirto dalam kegiatan Posyandu. Suatu hal yang menjadi permasalahan kajian ini adalah: bagaimana perkembangan pelaksanaan kegiatan program posyandu selama ini; bagaimana persepsi warga masyarakat desa terhadap program kegiatan posyandu; bagaimana bentuk-bentuk partisipasi masyarakat pada program kegiatan posyandu di desa selama ini; sejauh mana persepsi dan partisipasi masyarakat desa berkaitan dengan kondisi sosial, ekonomi, dan budayanya.

\section{B. Makna Sebuah Persepsi dan Partisipasi}

Menurut Davidoff, persepsi merupakan cara kerja atau proses yang rumit dan aktif, karena tergantung pada sistem sensorik dan otak (Davidoof, 1988: 237). Bagi manusia, persepsi merupakan suatu kegiatan yang pleksibel, yang dapat menyesuaikan diri secara baik terhadap masukan yang berubah-ubah. Dalam kehidupan seharihari, tampak bahwa persepsi manusia mempunyai kemampuan menyesuaikan diri dengan baik terhadap lingkungan dan budayanya. Dalam konteks ini, pengalaman-pengalaman pada berbagai kebudayaan yang berbeda dapat mempengaruhi bagaimana informasi penglihatan itu diproses. Pengalaman budaya berperan sangat penting dalam proses kognitif, karena tangapan dan pikiran yang merupakan alat utama dalam proses kognitif selalu bersumber darinya. Dengan demikian pengalaman seseorang yang merupakan akumulasi dari hasil berinteraksi dengan lingkungan hidupnya setiap kali dalam masyarakat, lokasi geografisnya, latar belakang sosial- 
ekonomi-politiknya, keterlibatan religiusnya, sangat menentukan persepsinya terhadap suatu kegiatan dan keadaan.

Karena kebudayaan dinyatakan sebagai segala sesuatu yang berhubungan erat dengan perilaku manusia dan kepercayaan, maka ia meliputi berbagai hal dalam kehidupan manusia, yang diantaranya adalah agama, pendidikan, struktur sosial ekonomi, pola kekeluargaan, kebiasaan mendidik anak, dan sebagainya. Dengan demikian dapat dikatakan bahwa kondisi kehidupan seseorang sehari-harinya sangat mempengaruhi persepsi pada setiap peristiwa sosial, dimana dalam setiap kegiatan sosial tersebut selalu melibatkan hubungan antar-subjek dan terbentuknya makna. Makna tersebut akan menentukan kesanggupan seseorang untuk terlibat dan berpartisipasi pada kegiatan tertentu dalam masyarakatnya (Sutopo, 1996: 133).

Dalam Kamus Besar Bahasa Indonesia, persepsi diintepretasikan sebagai tanggapan atau penerimaan langsung dari sesuatu, atau proses seseorang mengetahui beberapa hal melalui panca inderanya (Depdikbud, 1995:759). Persepsi selalu berkaitan dengan pengalaman dan tujuan seseorang pada waktu terjadinya proses persepsi. Ia merupakan tingkah laku selektif, bertujuan, dan merupakan proses pencapaian makna, dimana pengalaman merupakan faktor penting yang menentukan hasil persepsi (Sutopo, 1996:133). Tingkah laku selalu didasarkan pada makna sebagai hasil persepsi terhadap kehidupan para pelakunya. Apa yang dilakukan, dan mengapa seseorang melakukan berbagai hal, selalu didasarkan pada batasan-batasan menurut pendapatnya sendiri, dan dipengaruhi oleh latar belakang budayanya yang khusus (Spradly, 1980:137). Budaya yang berbeda, melatih orang secara berbeda pula dalam menangkap makna suatu persepsi, karena kebudayaan merupakan cara khusus yang membentuk pikiran dan pandangan manusia.

Dari teori-teori di atas, dapat dikemukakan bahwa persepsi merupakan proses aktif, dimana masing-masing individu menganggap, mengorganisasi, dan juga berupaya untuk mengintepretasikan yang diamatinya secara selektif. Oleh karena itu, persepsi merupakan dinamika yang terjadi dalam diri seseorang 
pada saat ia menerima stimulus dari lingkungan dengan melibatkan indra, emosional, serta aspek kepribadian lainnya. Dalam proses persepsi itu, individu akan mengadakan penyeleksian, apakah stimulus individu berguna atau tidak baginya, serta menentukan apa yang terbaik untuk dikerjakannnya.

Persepsi cenderung berkembang dan berubah, serta mendorong orang yang bersangkutan untuk menentukan sikap, karena tidak hanya terdiri dari being cognition yang pasif dan reseptif, tetapi juga jalan yang penuh keyakinan. Sifat aktif menyebabkan seseorang mampu melihat realitas yang terdalam dan tidak mudah terkelabuhi oleh penampakan realitas yang semu. Persepsi yang tajam menyebabkan seseorang memahami realitas diri dan lingkungannya dalam suatu interaksi interrasionalitas dengan totalitas dan tidak mudah terjebak pada salah satu pandangan yang empirisme.

Dalam kajian ini, persepsi masyarakat terhadap program posyandu, tidak hanya dilihat sebagai proses penerimaan stimulus dari luar dirinya, tetapi juga sikap batin yang mengarahkan seseorang mampu melihat hakekat yang terdalam dari urgensi pelaksanaan program posyandu yang diselenggarakan oleh pemerintah yang lebih bermakna. Persepsi positif masyarakat terhadap program posyandu, akan sangat menentukan kesanggupan mereka untuk terlibat dan berpartisipasi secara aktif dalam pelaksanaan program posyandu secara berkesinambungan. Partisipasi itu sendiri, menurut Purwodarminto, adalah suatu kegiatan atau turut berperan serta dalam suatu program kegiatan (Purwodarminto, 1984: 453). Partisipasi merupakan proses aktif yang mengkondisikan seseorang turut serta dalam suatu kegiatan yang disebabkan oleh persepsi yang positif. Meskipun demikian, partisipasi juga sangat dipengaruhi oleh kondisi sosiologisekonomis-politis seseorang yang merupakan latar belakang budaya yang berbeda-beda. Oleh karena itu, partisipasi masyarakat juga dapat berbeda-beda bentuknya. Tetapi dalam penelitian ini akan digambarkan secara komprehensif tampilan persepsi dan partisipasi dari masyarakat dalam studi kasus penelitian ini. 


\section{Fenomena Desa Giri Tirto}

Mulai tahun 2006, Desa Giritirto berada di bawah wilayah Kecamatan Purwosari Gunung Kidul Daerah Istimewa Yogyakarta. Sebelumnya, sebagaimana dalam proposal penelitian Dosen Muda yang diusulkan terdahulu, Desa Giritirto berada di bawah Kecamatan Panggang Kabupaten Gunung Kidul. Ini terjadi karena adanya program Pemerintah Kabupaten Gunung Kidul melalui program pemekaran kecamatan. Dengan adanya pemekaran ini, maka administrasi dan birokrasi semakin dekat, mengingat sebelumnya ibu kota Kecamatan Panggang cukup jauh dijangkau dari Desa Giritirto.

Pada awalnya, Kecamatan Panggang menempatkan Desa Giritirto sebagai wilayah Pembantu Kecamatan Panggang untuk urusan administrasi, sehingga untuk urusan administrasi desa-desa paling barat di Kecamatan Panggang, tidak perlu langsung ke pusat kecamatan yang letaknya cukup jauh itu, melainkan cukup ke Pembantu Kecamatan itu. Dalam perkembangannya, ketika kran pemekaran wilayah terbuka lebar, maka banyak daerah-daerah sampai kepada desa-desa untuk mengembangkan wilayah sendiri dan membentuk satuan administrasi sendiri. Begitu pula dengan desa-desa di Kecamatan Panggang paling Barat mengajukan pemekaran membentuk kecamatan sendiri. Berdasarkan hasil keputusan Pemerintah Kabupaten Gunung Kidul, maka terbentuklah kecamatan baru sebagai pecahan dari Kecamatan Panggang yakni Kecamatan Purwosari yang beribu kota atau berpusat di Desa Giritirto.

Secara geografis, Desa Giritirto memiliki wilayah perbatasan dengan Desa Selopamioro sebelah utara, Desa Giripurwo sebelah selatan, Desa Giriasih sebelah barat, dan Desa Giriharjo sebelah timur. Di antara desa-desa perbatasan tersebut, Desa Giritirto adalah desa yang paling kaya akan kesediaan air mengingat kebanyakan daerah di Gunung Kidul pada umumnya kekurangan air. Bahkan pada musim kemarau, Desa Giritirto menjadi pusat pengambilan air untuk konsumsi masyarakat di wilayah-wilayah lain di Gunung Kidul yang mengalami kekurangan air. Tampaknya sangat rasional, jika warga pendiri cikal-bakal desa menamakan desa ini Giritirto 
yang artinya pegunungan air mengingat wilayah ini kaya dengan sumber air.

Desa Giritirto, memiliki wilayah yang luasnya 1.179,0500 Ha, dengan perincian yakni: jalan panjangnya $41,0755 \mathrm{~km}$, sawah dan ladang 42,8871 $\mathrm{Ha}$, bangunan umum 1,1125 Ha, empang 0,1000 $\mathrm{Ha}$, pemukiman perumahan 80,1075 $\mathrm{Ha}$, dan pekuburan seluas 0,1075 Ha. Dalam pembagian wilayah, Giritirto terbagi menjadi 7 (tujuh) dusun yang masing-masing dikepalai oleh seorang Kepala Dukuh yang sebelumnya namanya Kepala Dusun. Dusun-dusun tersebut adalah Dusun Petoyan yang bahkan menjadi Pusat Kecamatan, Dusun Nglegok, Dusun Susukan, Dusun Tompak, Dusun Ploso, Dusun Gading, dan Dusun Blado. Jarak antar dusun cukup jauh sehingga terkadang menyulitkan koordinasi antar dusun jika ada kegiatan yang bersifat desa.

Aksesbilitas Desa Giritirto, menunjukkan bahwa jarak dari ibukota kabupaten adalah $43 \mathrm{~km}$, dan dari ibukota provinsi adalah 42 $\mathrm{km}$. Kondisi alam Desa Diritirto, ketinggian tanah dari permukaan laut adalah 500 meter dengan topografi dataran tinggi. Keadaan penduduk menurut jenis kelamin adalah laki-laki sebanyak 1.911 orang dan perempuan 2115 orang dengan jumlah kepala keluarga 653 orang. Dalam hal keagamaan, hampir 100 persen penduduk Giritirto beragama Islam. Hanya ada 4 penduduk yang beragama Katolik. Sedangkan untuk tingkat pendidikan lulusan SD sebesar 96.9 $\%$, SLTP $2 \%$, SLTA, $1 \%$, dan PT sebesar 0,1 \%.

Dalam hal sarana peribadatan, Giritirto memiliki 7 buah mesjid dan 1 buah puskesmas pembantu, 1 buah kelompok bermain, 1 buah Taman Kanak-kanak, dan 3 buah Sekolah Dasar. Dalam program Posyandu yang merupakan program nasional rincian jumlah akseptor KB adalah sebagai berikut. PIL 13 orang, IUD 356 orang, Suntik 13 orang, Kondom 71 orang, MOW 2 orang, dan KB mandiri 64 orang.

Sesuai dengan kondisi geografis, maka karakteristik masyarakat Desa Giritirto memiliki watak hudup yang keras atau tidak menyerah pada tantangan alam yang keras. Sedikitnya lahan pertanian untuk tanaman padi, menjadikan wilayah ini sering kekurangan makanan terutama nasi. Banyak penduduk yang masih 
mengkonsumsi tiwul, atau makanan pengganti nasi yang terbuat dari ketela pohon yang dikeringkan kemudian ditumbuk menjadi semacam nasi. Dalam hal penanaman ketela pohon saja, penduduk tidak memiliki lahan yang baik untuk keperluan penanamannya. Karena kebanyakan tanahnya bercampur dengan bebatuan, maka ketela pohon ditanam di sela-sela bebatuan dan buahnya tidak begitu besar.

Di lihat dari masalah kesukuan, hampir 100 persen penduduk bersuku Jawa yang memiliki adat budaya Jawa. Mayoritas tubuh mereka kecil-kecil, barangkali ada korelasinya dengan kondisi geografis yang cukup keras. Sesuai dengan tradisi masyarakat Jawa, maka kehidupannya masih menganut sistem kegotongroyongan yang cukup kuat. Dalam hal kebersamaan misalnya membangun rumah pribadi maupun sarana umum, masyarakat masih bahu membahu terlibat dalam kegotongroyongan.

Pola struktur pemerintahan Desa Giritirto terdiri atas Kepala Desa dan Badan Permusyawaratan Desa. Dalam melaksanakan tugasnya, kepala desa dibantu oleh perangkat desa yang terdiri atas: Sekretaris Desa, Kepala Urusan, dan Kepala Dukuh. Sebagai Kepala desa adalah Soewarno SP yang memimpin Desa giritirto selama 12 tahun, Kasim sebagai Sekretaris Desa, Suraji sebagai Kaur Pembangunan, Yasuki sebagai Kaur Pemerintahan, Hardjo Soewito sebagai Kaur Kesra, Sagiyo sebagai Kaur Keuangan, dan Diran sebagai Kaur Umum. Di samping itu, desa juga memiliki Tim Penggerak PKK yang berjumlah 10 orang di Desa, dan masingmasing 5 orang untuk setiap dukuh. Tugas Tim Penggerak PKK adalah untuk membantu masyarakat dalam rangka meningkatkan keterampilan dan kesejahteraan anggota keluarga. Kaitannya dengan penelitian ini, yakni pelaksanaan program Posyandu, maka peran besar Tim PKK cukup besar dalam hal menggerakan seluruh warga untuk ikut berpartisipasi.

\section{Serba-Serbi Implementasi Program Posyandu}

Sebagaimana telah diuraikan dalam deskripsi data umum mengenai kondisi geografi dan demografi penduduk Giritirto, maka masalah perekonomian juga sangat dipengaruhi oleh kondisi 
tersebut. Kebanyakan masyarakat hidup dari lahan pertanian yakni padi dan singkong. Namun demikian, untuk mempertahankan kehidupan sehari-hari, maka mereka juga bekerja sambilan seperti halnya kerajinan, berdagang, menjadi buruh, dan pekerjaanpekerjaan lain yang dapat menghasilkan uang. Pola bertahan hidup mereka menunjukkan keanekaragaman pencerminan yang menggambarkan karakteristik yang unik sebagai penduduk yang mendiami wilayah yang cukup menantang kehidupan.

Jumlah blok Posyandu yang ada di Desa Giritirto sebanyak 7 buah dimana masing-masing dukuh terdapat 1 buah blok Posyandu. Kaitannya dengan kondisi sosiologis masyarakat Desa Giritirto, pada umumnya mereka masih memiliki hubungan kekerabatan yang dekat. Stratifikasi sosial tidak begitu nampak, karena mereka memiliki tingkat kehidupan yang merata. Dapat dilihat pula dari tingkat penghasilan yang tidak terlalu jauh perbedaannya. Hal ini berkaitan dengan jenis pekerjaan yang mereka lakukan, dimana pada umumnya mereka hidup sebagai petani. Meskipun ada pekerjaan sambilan, tampaknya hanya sebatas membentuk pola bertahan hidup saja.

Dalam hal kondisi Puskesmas Desa Giritirto, tampaknya memerlukan perhatian yang serius mengingat saat ini Puskesmas yang rencananya akan dijadikan Puskesmas pusat kecamatan belum berfungsi sama sekali. Gedung yang rencananya akan digunakan tersebut adalah bangunan bekas kantor kecamatan cabang pembantu yang ada di selatan Giritirto. Letaknya juga tidak strategis, mengingat lokasinya yang jauh dari pusat kecamatan, dan bahkan jauh pula dari desa-desa lain yang tergabung dalam Kecamatan Purwosari. Kondisi ini diperparah dengan adanya gempa bumi yang melanda DIY dan Jawa Tengah pada 27 Mei 2006 yang dampaknya juga sangat hebat terasa di Gunung Kidul. Begitu pula dengan kondisi bangunan yang bakal dijadikan Puskesmas kecamatan kondisinya rusak parah. Dapat dilihat dalam gambar pada lampiran.

Sekarang ini, Puskesmas yang masih difungsikan oleh masyarakat, sebagaimana terlihat dalam lampiran, baik bangunan maupun fasilitasnya tidak memadai. Jumlah tenaga ahli kesehatan sangat terbatas tidak cukup untuk melayani masyarakat yang 
jumlahnya cukup besar. Hanya ada 1 dokter di sana di tambah 7 tenaga kesehatan. Puskesmas yang sekarang difungsikan ini, selain juga terkena gempa sehingga kondisinya juga cukup parah, hanya akan dijadikan sebagai puskesmas cabang pembantu. Jika dilihat dari lokasinya yang berada di pusat kecamatan, maka selaiknya justru bangunan puskesmas itu akan lebih fungsional jika dijadikan puskesmas pusat. Dengan demikian berarti harus ada perhatian yang serius dari pemerintah kabupaten terhadap eksistensi bangunan puskesmas yang fungsinya cukup besar itu. Jika perhatian pemerintah belum ada juga, maka pemerintah desa dapat mengupayakan usaha pembangunan agar puskesmas dapat berfungsi secara maksimal.

Di Giritirto, terdapat 176 balita dan 98 ibu menyusui. Dalam kegiatan Posyandu, banyak komponen atau elemen yang terlibat baik secara langsung maupun tidak langsung. Pada dasarnya, masyarakat siap dalam melaksanakan program posyandu yang telah menjadi program pemerintah. Masyarakat berperan serta dalam mengikuti kegiatan program posyandu. Namun demikian, tingkat keberhasilan program akan sangat tergantung pada ketercapaian tujuan oleh realitas implementasi di lapangan. Sejauh mana penerimaan masyarakat terhadap kegiatan program tersebut, akan sangat dipengaruhi oleh ketepatan sasaran program posyandu. Berdasarkan pengamatan langsung, maka tampaknya ketercapaian tujuan program tersebut masih perlu dijadikan perhatian mengingat masih lemahnya kontrol program terpadu ini.

Dalam implementasi kegiatan program selama ini, tentunya banyak sekali faktor-faktor baik yang mendukung maupun yang menghambatnya. Tingkat pendidikan tenaga ahli dan masyarakat itu sendiri, keterlibatan penuh tokoh masyarakat, LSM, Tim Penggerak PKK, kepala desa dan perangkat desa, keterlibatan dasa wisma, serta komitmen pemerintah kabupaten, akan sangat berpengaruh terhadap tingkat keberhasilan program. Faktor-faktor inilah yang masih belum diperhatikan secara optimal, sehingga implementasi program sesuai dengan harapan yang ingin dicapai.

Dalam hal persepsi masyarakat, tenaga ahli kesehatan, dan para tokoh masyarakat terhadap pelaksanaan program posyandu 
adalah positif. Mereka menganggap penting dilaksanakannya program tersebut, tidak hanya sekedar melaksanakan program formal dan rutinitas belaka, melainkan juga substansinya yang besar bagi peningkatan kualitas kehidupan manusia, terutama yang menyangkut masalah kesehatan. Dengan persepsi yang positif, maka partisipasinya dalam pelaksanaan kegiatan tersebut juga cukup tinggi. Namun demikian, tampaknya yang masih perlu diluruskan adalah pemahaman yang masih terlalu sederhana tentang program tersebut. Dalam pandangan masyarakat, program posyandu adalah program rutin setiap bulan dalam rangka melakukan penimbangan balita untuk melihat perkembangan balita. Pandangan ini masih terlalu sempit karena sebenarnya posyandu tidak hanya untuk pelaksanaan program penimbangan balita saja, melainkan juga sebagai pusat pelayanan kesehatan terpadu yang juga dapat dilakukan dalam rangka memberikan pelayanan kesehatan masyarakat.

Faktor-faktor yang mendorong masyarakat dalam berpartisipasi dalam kegiatan program itu adalah selain hal tersebut sudah menjadi tradisi yang rutinitas, kesehatan balita mereka menjadi perhatian utama. Namun sebagai penghambat pelaksanaan program tersebut adalah masih rendahnya tingkat mayoritas masyarakat, di samping itu juga para tenaga ahli kesehatan tidak memberikan pelayanan yang lebih responsif terhadap masyarakat. Hal ini juga salah satunya diakibatkan oleh masih rendahnya wawasan dan pendidikan para tenaga ahli. Sedangkan keterlibatan perangkat desa dalam pelakksanaan program ini adalah dengan memberikan fasilitas desa maupun dusun untuk pelaksanaan kegiatan tersebut, di samping memberitahu ketika akan dilaksanakan kegiatan tersebut.

Sedangkan keterlibatan tokoh masyarakat dalam pelaksanaan program tersebut adalah dengan memberikan ceramah-ceramah terhadap masyarakat akan pentingnya program tersebut bagi kelangsungan kehidupan yang normal dan lebih baik. Masalah yang menyangkut masalah obat-obatan sebagai pendukung pelaksanaan program merupakan kebijakan pemerintah yang didistribusikan 
secara proporsional sesuai dengan jumlah masyarakat dalam suatu wilayah.

Dalam pandangan tenaga ahli kesehatan, masyarakat cenderung menerima dengan baik terhadap program tersebut. Masyarakat siap dalam merealisasikan program tersebut terutama mengenai keterlibatan Tim Penggerak PKK yang aktif dalam mendukung kegiatan tersebut. Para tenaga ahli juga menilai bahwa fasilitas baik bangunan maupun yang lain masih sangat minim, sehingga perlu diupayakan secara permanen sehingga dapat menunjang program pemerintah tentang kesehatan masyarakat. Dalam hal gedung saja masih sangat memprihatinkan. Para tenaga ahli juga melihat persepsi dan keterlibatan masyarakat cukup baik, sehingga program tersebut secara rutin dapat dilaksanakan setiap bulan.

Dalam hal lain yang masih berhubungan dengan kegiatan ini, para tokoh masyarakat juga cenderung melihat positif terhadap program itu. Dengan demikian, mereka juga secara tidak langsung terlibat juga dalam implementasi program. Dalam pada itu, para tokoh masyarakat melihat adanya karakteristik ekonomi, pendidikan, budaya, dan sosial masyarakat sangat berpengaruh terhadap tingkat penerimaan program tersebut. Dengan tingkat kompleksitas karakteristik masyarakat yang masih sangat sederhana, maka realitas implementasi rpogram juga dilaksanakan dalam kerangka kerja yang sederhana pula.

Di Desa giritirto, pelaksanaan program posyandu dilaksanakan setiap tanggal 4 awal bulan. Sebagaimana telah diuraikan di muka, maka pelaksanaan program posyandu di Desa Giritirto juga dalam rangka untuk penimbangan Balita. Hal ini diungkapkan oleh Sagiyo dalam wawancara bahwa kegiatan dilaksanakan secara rutin setiap bulan. Begitu pula dengan penuturan Haryati dan Wasmi yang setiap bulan mengikuti program posyandu dalam rangka penimbangan balita nya. Haryani juga mengungkapkan bahwa wawasan masyarakat tentang program posyandu masih sangat sederhana, sehingga perlu adanya intensifitas pelaksanaan program sehingga substansi yang sesungguhnya dari program tersebut dapat tercapai. 
Suksesnya suatu program dalam hal ini program Posyandu, tergantung dari aktif atau tidak aktifnya partisipasi masyarakat untuk mensukseskan program tersebut. Sehingga dalam posisi ini peran aktif masyarakat sangat penting artinya bagi kelancaran dan keberhasilan program tersebut dan tercapainya tujuan secara mantap. Program Posyandu dicanangkan dalam rangka usaha pemerintah untuk membangun manusia Indonesia yang berkualitas. Pada dasarnya pemerintah berkeinginan untuk membuat perubahan dari suatu kondisi tertentu ke keadaan lain yang lebih bernilai. Agar proses perubahan itu dapat menjangkau sasaran-sasaran perubahan keadaan yang lebih baik dan dapat digunakan sebagai pengendali masa depan, di dalam melaksanakan pembangunan itu perlu sekali memperhatikan segi manusianya. Karena dalam arti proses, pembangunan itu menyangkut makna bahwa manusia itu obyek pembangunan dan sekaligus subyek pembangunan. Sebagai subyek pembangunan manusia harus diperhitungkan, sebab dia punya nilai dan potensi yang luar biasa. Oleh karena itu, di dalam pembangunan bangsa perlu melibatkan secara intensif subyek untuk ikut berpartisipasi aktif dalam pembangunan (Pasaribu dan Simanjutak, 1986: 62).

Hambatan yang sering muncul ketika partisipasi masyarakat terhadap suatu program pemerintah kurang maksimal bisa secara internal, berupa hambatan sosio-kultural, dan eksternal, hambatan dari birokrasi pemerintah (Miftah Thoha,tth: 11-17). Hambatan internal, merupakan hambatan dari dalam masyarakat itu sendiri, yang merupakan keengganan sebagian besar warga masyarakat untuk terlibat langsung dalam suatu program kegiatan. Hal ini disebabkan karena keadaan sosio-kultural mereka yang belum memungkinkan untuk secara aktif menyuarakan keinginan mereka. Sementara mereka lebih memilih diam. Hambatan ini bukanlah merupakan hambatan yang fatal, sebab hambatan ini masih bisa diperbaiki dengan cara memberikan masukan informasi-informasi baru yang positif dan bersifat membangun. Mereka harus dikenalkan dengan penemuan-penemuan dan perkembangan baru di daerah lain, yang nantinya akan membuka cakrawala berpikir mereka. Akan tetapi kadang-kadang mereka masih memiliki kesadaran yang 
rendah karena adanya beberapa keterbatasan. Misalnya: rendahnya pendidikan, rendahnya sosial-ekonomi, kurangnya sarana dan prasarana.

Pengendalian pertumbuhan penduduk merupakan unsur penting dalam pembangunan ekonomi. Program Posyandu di Indonesia dapat berhasil karena ditopang oleh kemajuan pendidikan, peningkatan mobilitas penduduk, bertambahnya angkatan kerja, dan lain-lain. Tetapi, masalah internalisasi motivasi melaksanakan posyandu tampaknya masih merupakan persoalan tersendiri. Masalah internalisasi motivasi melaksanakan Posyandu merupakan persoalan yang sentral. Berhubungan pendekatan selama ini adalah supply oriented di mana masyarakat didorong menggunakan fasilitas kesehatan dengan cuma-cuma lalu didukung oleh sistem target maka ketergantungan adalah produk dari strategi itu sendiri. (Masri Singarimbun, 1988: 15). Selama ini mereka yang mampu juga mendapat subsidi dalam bentuk layanan yang cuma-cuma. Diharapkan program posyandu akan semakin meluruskan hal ini dan kemudian tertanam internalisasi motivasi implementasi posyandu pada masyarakat secara keseluruhan.

Program posyandu di Indonesia yang secara resmi diintegrasikan dalam program pembangunan sejak tahun 1970-an secara umum dapat dikatakan berhasil. Kelancaran dari program ditopang oleh perkembangan yang pesat dalam kemajuan sosial ekonomi, kemajuan pendidikan, bertambahnya mobilitas penduduk, bertambahnya wanita dalam angkatan kerja, meningkatnya pendapatan perkapita, dan lain-lain. Di samping itu, juga ditopang oleh stabilitas politik dan komitmen pemerintah yang besar terhadap program ini. Media massa, jaringan jalan, transportasi, jumlah fasilitas kesehatan, maju dengan pesat (Geoffrey Mc Nicoll, 1983: 14).

Salah satu aset dari program pembangunan di Indonesia adalah struktur sosial tradisional yang masih tetap bertahan di desa dan unit yang lebih kecil dari desa. Unit tersebut adalah juga unit administrasi pemerintah. Berbagai instruksi yang datang dari pusat dapat mencapai desa dalam waktu yang relatif singkat dan menyusupi seluruh pelosok tanah air. Program itu kemudian diimplementasikan di tingkat desa dan dusun. Tidak adanya 
lembaga seperti itu untuk dijadikan ujung tombak merupakan penghalang yang penting di berbagai negara seperti umpamanya di India, Nigeria, dan lain-lain.

Dalam rangka memantapkan dan menyempurnakan kebijakan pengelolaan gerakan PKK kurun waktu lima tahun kedepan, pedoman administrasi PKK mengalami perubahan mendasar dalam kelembagaan kesejahteraan keluarga antara lain adalah:

1. Pengertian PKK menjadi lebih lengkap dan secara kelembagaan lebih gender responsif.

2. Agar lebih operasional sebutan badan penyantun tim penggerak PKK berubah menjadi dewan penyantun tim penggerak PKK.

3. Sebagai wujud kepedulian, keteladanan/panutan dan tanggung jawab terhadap pemberdayaan dan kesejahteraan keluarga/ ketua tim penggerak PKK desa dan kelurahan/secara fungsional dijabat oleh isteri kepala desai lurah/sama dengan ketua tim penggerak PKK diatasnya.

4. Sebagai perwujudan PKK yang merupakan gerakan nasional dari pusat sampai dengan desa/kelurahan dan untuk lebih mengharmoniskan hubungan kerja secara hirarkis antara tim penggerak PKK pusat atau tim penggerak PKK provinsi/dengan tim penggerak PKK di bawahnya/termasuk mekanisme pembinaan/bimbingan dan pelaporannya/maka penetapan dan pelantikan ketua tim penggerak PKK dilakukan oleh ketua umum/ketua tim penggerak PKK setingkat diatasnya serta dikukuhkan oleh gubernur, bupatl/walikota, camat, kepala desa/lurah setempat.

5. Untuk meningkatkan persatuan dan kesatuan serta memperkuat jiwa kebersamaan segenap jajaran PKK, telah diputuskan adanya seragam nasional PKK, yang dipergunakan pada acara-acara tertentu, disamping masih tetap adanya kembaran PKK daerah masing-masing.

6. Gerakan PKK didorong untuk lebih meningkatkan jaringan kerjasama dan kemitraan dengan sektor pemerintah, badan international, dunia usaha, lembaga kemasyarakatan 
setempat, sesuai dengan kepentingan dan kebutuhan serta mekanisme koordinasi yang berlaku.

7. 10 program pokok PKK tidak mengalami perubahan karena dinllai masih relevan. Dalam pelaksanaannya, prioritas 10 program pokok PKK, diserahkan kepada daerah, disesualkan dengan situasi, kondisi dan kemampuan yang ada, sehingga tidak merupakan "paksaan" dari "atas" melainkan merupakan "kesadaran" dalam membangun dirinya/daerahnya.

8. Keberadaan kelompok-kelompok PKK dan dasawisma menjadi sangat penting dan lebih strategis, karena dasawisma adalah unit terdepan dalam gerakan PKK. Apabila kelompok dasawisma ini berfungsi dengan balk, kita akan mendapatkan data-data keluarga yang akurat dan sebagai salah satu wahana bagi masyarakat untuk melaksanakan kegiatan dan berinteraksi secara langsung dengan anggota kelompok dasawismanya.

9. Perhatian khusus perlu diberlkan kepada posyandu, sebagai wadah terdepan dalam pemberian pelayanan kesehatan dasar. Posyandu tidak hanya bekerja satu kali dalam satu bulan, tetapi 30 hari, hanya hari buka posyandu satu kali dalam satu bulan.

Ditemukannya kasus gizi buruk dan kurang gizi di berbagai daerah, mengingatkan kita semua bahwa sesuatu kegiatan/program tidak hanya selesai setelah waktu kegiatan berakhir tetapi semua kegiatan perlu ditindak lanjuti melalui pemantauan dan pembinaan, begitu seterusnya. Kelompok dasawisma dan posyandu merupakan salah satu institusi yang sangat potensial yang ada diakar rumput. Seluruh jajaran tim penggerak PKK di semua jenjang agar segera membentuk dan menghidupkan kembali kelompok dasawisma dan posyandu seperti yang telah diamanatkan oleh presiden beberapa waktu yang lalu, betapa pentingnya revitalisasi posyandu dan kegiatan/kegiatan PKK lainnya.

Harapan kita kepada jajaran tim penggerak PKK untuk betulbetul meningkatkan penyuluhan-penyuluhan masalah ini, balk yang sifatnya umum, maupun pelaksanaan kegiatan 10 program pokok PKK lainnya. Perlu pula diinformaslkan kegiatan pendidlkan dan 
pembinaan sikap mental, khususnya bagi anak dan remaja, serta penanggulangan kekerasan dalam rumah tangga dan trafficking/perdagangan anak. Ditingkatkan dan kembangkan program pendidikan anak usia dini (paud) yang dalam pelaksanaannya dapat diintegrasikan dengan kegiatan posyandu, juga perlu diperhatikan peningkatan ekonomi keluarga melalui peran PKK, pemahaman tentang pangan yang beragam, bergizi dan berimbang, serta disebarluaskannya pengertian "hatinya PKK".

\section{E. Kesimpulan}

Dalam seri penutup ini dapat disimpulkan temuan-temuan pokok sebagai berikut.

1. Bahwa selama ini program posyandu di Desa Giritirto dilaksanakan secara rutin dan atau bahkan telah menjadi tradisi masyarakat.

2. Terhadap program posyandu, baik masyarakat, tokoh masyarakat, maupun para tenaga ahli kesehatan persepsinya adalah positif sehingga dalam hal berpartisipasinya juga cukup tinggi.

3. Bentuk-bentuk partisipasi masyarakat terhadap program posyandu terbatas pada pengertian dan pemahaman mereka tentang program posyandu. Masyarakat yang paling berpartisipasi adalam mereka yang memiliki balita. Sedangkan partisipasi petugas puskesmas adalah memberikan pelayanan terhadap perkembangan balita. Sementara tokoh masyarakat dan perangkat desa terbatas pada memberikan himbouan dan fasilitas desa untuk kegiatan posyandu.

4. Kaitan antara persepsi dan partisipasi sangat berkaitan dengan latar belakang ekonomi, budaya, dan sosialnya. Karakteristik kehidupan yang masih sangat sederhana, mengkondisikan perilaku yang sederhana pula dalam kehidupan sehari-hari.

Kita menyadari bahwa keberhasilan pelaksanaan programprogram kesejahteraan keluarga sangat ditentukan oleh adanya keterpaduan antara gerakan keswadayaan dan partisipasi 
masyarakat dengan bimbingan dan fasilitasi teknis dari berbagai instansi/lembaga terkait, yang terwadahi dalam dewan penyantun tim penggerak PKK. Informasi secara garis besar tentang posisi dan peranan gerakan PKK seperti itu, sesungguhnya sudah dapat menggambarkan betapa strategisnya fungsi TPPKK beserta kaderkader PKK yang tersebar diseluruh pelosok desa. TP PKK dapat menjadi perekat antara fungsi-fungsi kemasyarakatan dan fungsifungsi pemerintahan. TP PKK juga dapat berperan sebagai unsur terdepan yang akan menggalang peran-serta masyarakat.

Program-program pemerintah dan pemerintah daerah yang berkaitan langsung dengan peran-serta masyarakat, sewajarnya memperoleh dukungan dari TP PKK. Terhadap hal ini, ada faktor kunci agar TP PKK mampu melakukan fungsinya secara optimal, antara lain, perlunya segenap jajaran TP PKK mengetahui apa yang menjadi program-program pemerintah. Tetapi ini bukan berarti, TP PKK hanya mengerjakan apa yang menjadi program-nya pemerintah saja, karena pada hakekatnya TP PKK itu memiliki 10 program pokok PKK yang perlu dilaksanakan bersama, kemudian dalam pelaksanaan 10 program pokok itu, TP PKK perlu berkoordinasi dengan dinas/instansi pemerintah maupun instansi lainnya.

\section{Kepustakaan}

Davidoff, LL. 1988. "Introduction To Psychology", alih bahasa Mari Juniati, Psikologi Suatu Pengantar Jilid I. Jakarta: Erlangga.

Departemen Pendidikan dan Kebudayaan, 1995. Kamus Besar Bahasa Indonesia Edisi Kedua. Jakarta: Balai Pustaka.

Krippendorff, Klaus. 1991. Content Analysis: Introduction Its Theory and Methodology", Alih Bahasa Farid Wajidi, Analisis Isi: Pengantar Teori dan Metodologi. Jakarta: Rajawali.

Miles, M.B. and Huberman, A.M. 1984. Qualitative Data Analysis: A Sourcebook of New Methods. Beverly Hills CA: Sage Publications.

Moleong, L.J. 1999. Metodologi Penelitian Kualitatif. Bandung: Remaja Rosdakarya. 
Muhadjir, Noeng. 1996. Metodologi Penelitian Kualitatif. Yogyakarta: Rake Sarasin.

Patton, M.Q. 1980. Qualitative Evaluation Methods. Beverly Hills, CA.: Sage Publication.

Spradley, J.P. 1980. Participant Observation. New York, N.Y.: holt, Rinehart, and Winston.

Sutopo, H.B. 1995. Kritik Seni Holistik Sebagai Model Pendekatan Penelitian Kualitatif. Surakarta: UNS Press.

Sutopo, H.B. 1996. Metodologi Penelitian Kualitatif. Surakarta: Jurusan Seni Rupa Fakultas Sastra UNS.

Waluyo, H.J. 2000. "Hermeneutik Sebagai Pusat Pendekatan Kualitatif", dalam Historika, No.11. Surakarta: PPS UNJ KPK UNS.

Yin, R.K. 1987. Case Study Research: Design and Methods. Beverly Hills, CA: Sage Publication.

\section{Tentang Penulis :}

Puji Lestari, M.Hum. Dosen Program Studi Pendidikan Sosiologi di Jurusan Pendidikan Sejarah Fakultas Ilmu Sosial dan Ekonomi Universitas Negeri Yogyakarta. Menamatkan program S-1 Sosiologi FISIPOL UGM pada tahun 1982. Menyelesaikan program Pasca Sarjana S-2 Antropologi FIB UGM tahun 2003. Bidang Keahlian Sosiologi Antropologi. Mata kuliah yang diampu saat ini adalah : Pranata Sosial, Sistem Sosial, Sosiologi Perkotaan, Sosiologi Komunikasi, Demografi. 